\title{
Microstructural chromosome reorganization in the genus Trichomycterus (Siluriformes: Trichomycteridae)
}

\author{
Maria Lígia M. de Oliveiraㄹ, Ricardo Utsunomia ${ }^{1}$, José Carlos Pansonato-Alves ${ }^{1}$, \\ Priscilla C. Scacchetti ${ }^{1}$, Cleberson C. Primo ${ }^{2}$, Marcelo R. Vicari ${ }^{2}$, Roberto F. Artoni ${ }^{2}$, \\ Liano Centofante ${ }^{3}$, Orlando Moreira-Filho ${ }^{4}$, Claudio Oliveira ${ }^{1}$ and Fausto Foresti ${ }^{1}$
}

Trichomycterus is a specious fish genus within Trichomycterinae and displays remarkable karyotype diversity. However, knowledge about their genomic structure and location of repetitive sequence is still limited. In order to better understand the karyotype diversification, we analyzed nine species of Trichomycterus using classical and molecular cytogenetic techniques. Results revealed a conserved diploid chromosome number of $2 \mathrm{n}=54$ chromosomes in all analyzed species, although remarkable differences on the constitutive heterochromatin distribution were observed. In addition, while the 18S rDNA showed a conserved distribution pattern, the 5S rDNA sites showed a quite diverse location considering the analyzed species. Remarkably, both ribosomal genes were co-located in all species, except in T. iheringi, suggesting that co-localization is probably an ancestral condition in Trichomycterus. Finally, three analyzed species showed heterochromatic B chromosomes, reinforcing the intense genomic reorganization occurring in Trichomycterus. Our results showed that chromosomal variations are not restricted to differences in karyotype formula as previously proposed, but also to modifications on the microstructural level of resolution.

Trichomycterus é um especioso gênero dentro de Trichomycterinae e exibe marcante diversidade cariotípica. No entanto, o conhecimento sobre sua estrutura genômica e localização de seqüências repetitivas ainda é restrita. Para um melhor conhecimento sobre a sua diversificação cariotípica, nós analisamos nove especies de Trichomycterus usando técnicas de citogenética clássica e molecular. Os resultados revelaram um conservado número diploide de $2 n=54$ cromossomos em todas as espécies analisadas, embora diferentes marcações na distribuição da heterocromatina constitutiva tenham sido observadas. Além disso, enquanto o DNAr 18S mostrou um padrão de distribuição conservado, os sítios de DNAr 5S mostraram uma localização bastante diversa, considerando as espécies analisadas. Ambos os genes ribossomais foram co-localizados em todas as espécies, exceto em T. iheringi, sugerindo que a co-localização é provavelmente uma condição ancestral em Trichomycterus. Finalmente, três espécies analisadas mostraram cromossomos B heterocromáticos, reforçando uma intensa reoganização genômica ocorrendo em Trichomycterus. Nossos resultados mostraram que variações cromossômicas não estão restritas à diferenças na fórmula cariotípica, como proposto anteriormente, mas também às alterações a níveis de resolução estrutural.

Keywords: Karyotype diversity, Repetitive DNA, rDNA, Supernumerary chromosomes.

\section{Introduction}

Trichomycterus is a fish genus within Trichomycteridae family that comprises small sized species popularly known as "cambevas". This group presents approximately 160 valid species (Froese \& Pauly, 2014) with a wide distribution in the Neotropical region (Sarmento-Soares et al., 2011). In general, the species exhibit a wide variety of forms and constitute isolated populations in headwater streams, resulting in a high degree of endemism (de Pinna \& Wosiacki, 2003; Wosiacki \& Garavello, 2004; Wosiacki $\&$ de Pinna, 2007).

\footnotetext{
${ }^{1}$ Departamento de Morfologia, Instituto de Biociências de Botucatu, Universidade Estadual Paulista, Distrito de Rubião Junior, s/n, 18618-970 Botucatu, SP, Brazil. (MLMO) marialigia25@gmail.com (corresponding author), (RU) utricardo@ibb.unesp.br, (JCP-A) jcpansonato@gmail.com, (PCS) pcardim@hotmail.com, (CO) claudio@ibb.unesp.br, (FF) fforesti@ibb.unesp.br

${ }^{2}$ Departamento de Biologia Estrutural, Molecular e Genética, Programa de Pós-Graduação em Biologia Evolutiva, Universidade Estadual de Ponta Grossa, Av. Carlos Cavalcanti, 4748, 84030-900 Ponta Grossa, PR, Brazil. (CCP) cleberprimo@yahoo.com.br, (MRV) vicarimr@yahoo.com.br, (RFA)rfartoni@gmail.com

${ }^{3}$ Instituto de Biociências, Universidade Federal de Mato Grosso, Av. Fernando Correa da Costa S/N Coxipó, 78068-000 Cuiabá, MT, Brazil. (LC)lianocentofante@yahoo.com.br

${ }^{4}$ Departamento de Genética e Evolução, Universidade Federal de São Carlos, Rodovia Washington Luís, Km 235, 13565-905 São Carlos, SP, Brazil. (OMF) omfilho@ufscar.br
} 
Early cytogenetic studies in Trichomycterus evidenced a considerably variable karyotype, with the diploid chromosome numbers ranging from $2 n=50$ in Trichomycterus sp. to $2 \mathrm{n}=62$ in T. laucaensis (Arratia \& Veloso, 1980). Remarkably, Sato et al. (2004) stated that such notable differences might be found only in transAndean species, while cis-Andean species have retained a conserved diploid number of 54 chromosomes, except T. diabolus from Tietê River, which has been described with $2 \mathrm{n}=56$ chromosomes (Torres et al., 2004). In addition, variations in the chromosomal location of the nucleolar organizer regions (NORs) and even the occurrence of supernumerary chromosomes were already reported in this group (Borin \& Martins-Santos, 2000; Torres et al., 2002).

In the present study, we performed a comparative chromosome analysis among nine species of Trichomycterus collected in different Brazilian river basins using classical and molecular cytogenetic methods. The main purpose of this study was to better understand the mechanisms involved in karyotype diversification in this fish group by mapping the location of some repetitive genes in the genome and comparing chromosomal aspects of several Trichomycterus species.

\section{Material and Methods}

Nine species of Trichomycterus from different Brazilian river basins were analyzed (Table 1). After identification, the specimens were fixed and deposited in the fish collection of the Laboratório de Biologia e Genética de Peixes, Universidade Estadual Paulista, Botucatu, São Paulo (LBP), in the Museu de Zoologia, Universidade Estadual de Londrina, Londrina, Paraná (MZUEL) and Museu Nacional, Universidade Federal do Rio de Janeiro, Rio de Janeiro, (MNRJ) (Table 1). The samples were collected in accordance with Brazilian environmental protection legislation (Collection Permission MMA/ IBAMA/SISBIO - number 3245 ) and the procedures for sampling, maintenance and analysis of the individuals were performed in accordance with the international protocols on animal experimentation followed by the São Paulo State University (Protocol CEEAA/IBB/UNESP - number 405).
The specimens were anesthetized with a lethal dose of benzocaine before chromosome preparation procedures. In order to stimulate cell division and obtain metaphase chromosomes, the technique described by Cole \& Levans (1971) for amphibians and reptiles and later adapted for fish by Oliveira et al. (1988) was used. Chromosome preparations followed the protocol described in Foresti et al. (1981). The heterochromatic regions were evidenced according to Sumner (1972). The 5S and 18S rDNA sequences were amplified using the primers 5S-A (5'TAC GCC CGA TCT CGT CCG ATC-3') and 5S-B (5'CAG GCT GGT ATG GCC GTA AGC-3') (Pendas et $a l ., 2004)$ and NS1 (5'-GTA GTC ATA TGC TTG TCT T-3') and NS8 (5'-TCC GCA GGT TCA CCT ACG GA3') (White et al., 1990), the FISH analyses were based on the method of Bonillo et al. (2015) with modifications. The images were captured with a digital camera (Olympus DP70) attached to an Olympus BX61 epifluorescence photomicroscope. The chromosomes were classified as metacentric (m), submetacentric $(\mathrm{sm})$ and subtelocentric (st) according to their arm ratios (Levan et al., 1964) and arranged in decreasing size within each class.

\section{Results}

All the analyzed Trichomycterus species showed a conserved diploid number of $2 \mathrm{n}=54$ chromosomes. However, a considerable diversity concerning the karyotypes formulas was identified among all the analyzed species (Table 1). Moreover, T. paulinus, Trichomycterus sp. 1, and Trichomycterus sp. 3 presented mitotically unstable supernumerary chromosomes, which ranged from 0 to 7, 0 to 3 and 0 to $3 \mathrm{~B}$ chromosome per cell, respectively (Table 1). A variable pattern of size involving the first two chromosome pairs was identified in the karyotypes. Thus, in the species $T$. mimonha, $T$. zonatus, T. iheringi and Trichomycterus sp. 2, the first metacentric pair is the largest in the karyotype, while in T. diabolus, Trichomycterus sp. 3, Trychomycterus sp. 1, T. davisi and T. paulinus the first and second metacentric pairs are similar in size and the largest ones in the karyotype (Figs. 1-2).

Table 1. Species of Trichomycterus analyzed in the study indicating the collection sites, diploid number, occurrence of B chromosomes and karyotypic formula.

\begin{tabular}{|c|c|c|c|c|}
\hline Species and number identification & Locality and Coordinates & $2 n$ & Karyotype Formulae & B chromosomes \\
\hline T. iheringi (LBP 10878) & Roseira River - Tietê - Bofete - SP 2301'30'S 48¹9'50'”W & 54 & $34 m+12 s m+8 s t$ & - \\
\hline T. diabolus (LBP 10879) & Hortelã River - Paranapanema - Botucatu - SP 2255'24”S 48³2’43”'W & 54 & $34 m+12 s m+8 s t$ & - \\
\hline T. zonatus (LBP 10877) & Grande River - Costeira do Sudeste - Ubatuba - SP 23²3'41"S 4507'17'W & 54 & $34 \mathrm{~m}+12 \mathrm{sm}+8 \mathrm{st}$ & - \\
\hline T. mimonha (LBP 10876) & Muzambo River - Grande - Muzambinho - MG 21²0’46”S 46³0’47’'W & 54 & $34 m+12 s m+8 s t$ & - \\
\hline T. paulinus (UEPG 1687) & Verde River - Alto Tibagi - Ponta Grossa - PR 2504’35”S 5004’03”W & 54 & $40 \mathrm{~m}+10 \mathrm{sm}+4 \mathrm{st}$ & $0-7$ \\
\hline T. davisi (UEPG 2216) & Areia Stream - Ribeira de Iguape - Ponta Grossa - PR 2508'08”S 4951'23”'W & 54 & $28 \mathrm{~m}+18 \mathrm{sm}+8 \mathrm{st}$ & - \\
\hline Trichomycterus sp. 1 (UEPG 1770) & Verde River - Alto Tibagi - Ponta Grossa - PR 2504’35’S 5004’03”'W & 54 & $42 \mathrm{~m}+12 \mathrm{sm}$ & $0-3$ \\
\hline Trichomycterus sp. 2 (UEPG 1650) & Preto Stream - Visconde de Mauá - RJ 22¹9'56,48’S 44³2’39,02”W & 54 & $44 m+10 s t$ & - \\
\hline Trichomycterus sp. 3 (LBP 19564) & Quinta Stream - Itatinga - SP 2306'30,7’S 48³0'18,1'W & 54 & $36 \mathrm{~m}+10 \mathrm{sm}+8 \mathrm{st}$ & $0-3$ \\
\hline
\end{tabular}




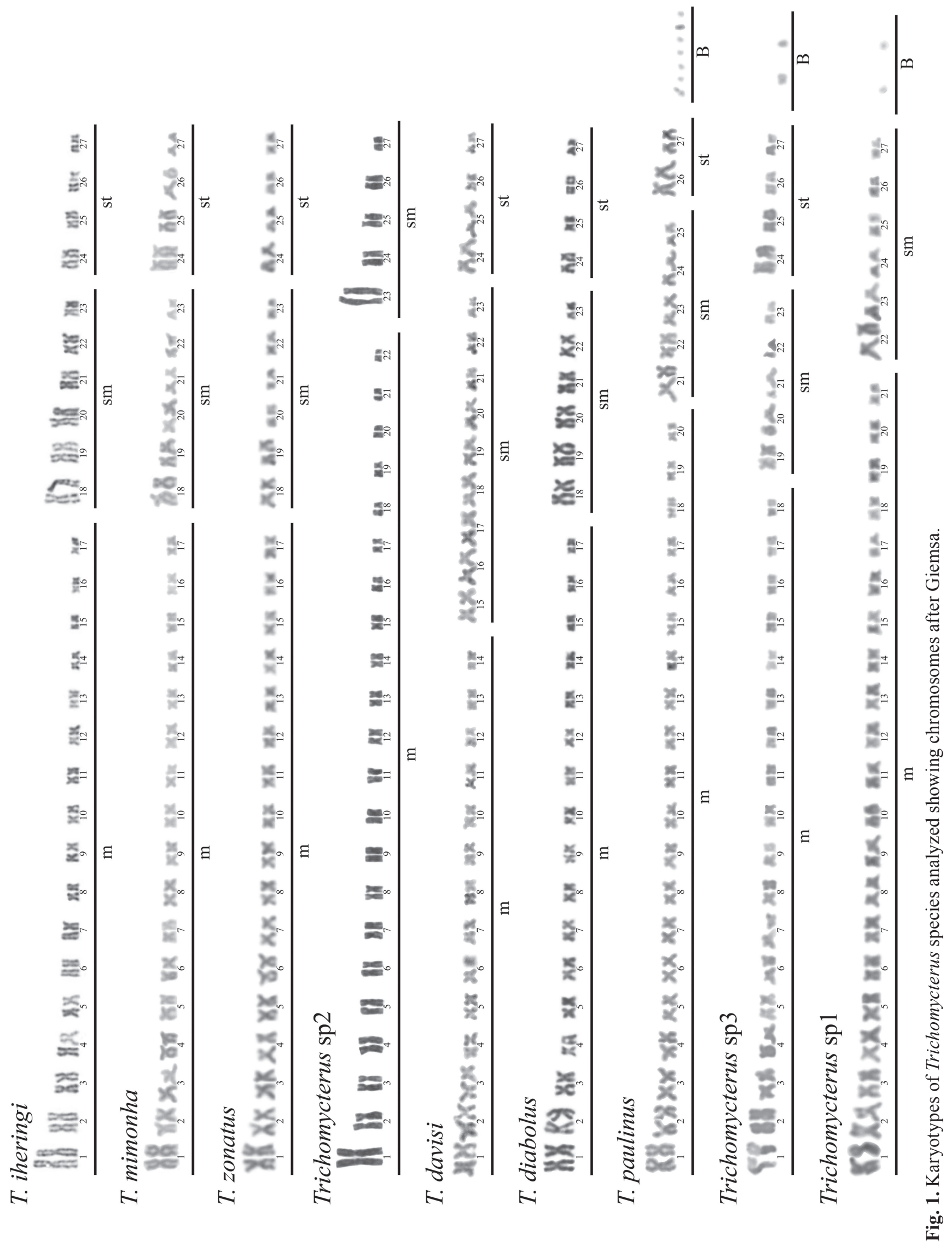




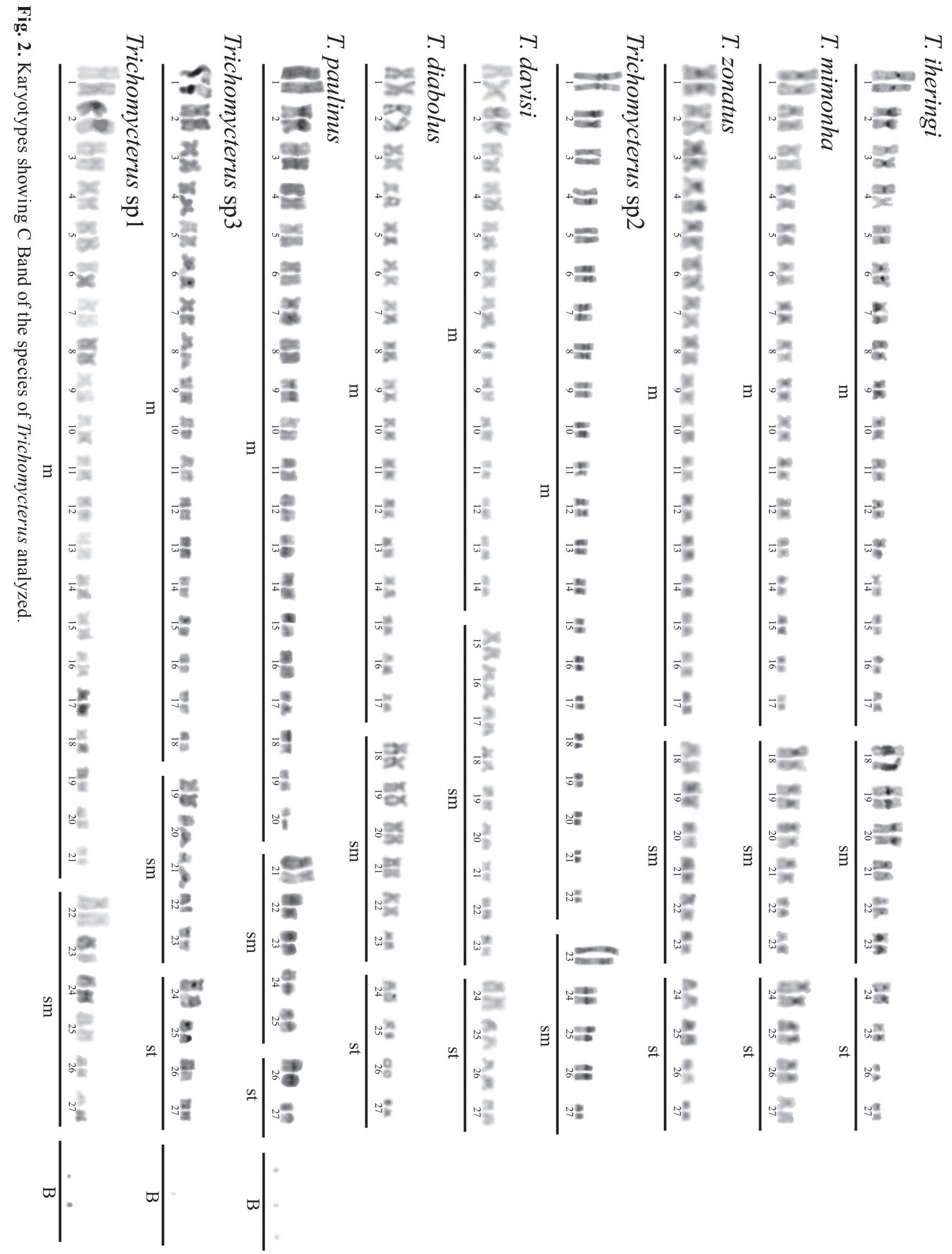


Differences in the C-banding patterns were observed. As a rule, all the species presented heterochromatic blocks associated to the $18 \mathrm{~S}$ rDNA regions. Besides that, additional interstitial heterochromatic blocks were observed in certain species, like in $T$. iheringi (pairs nos. 2, 3, 7, 8, 19, 23) and $T$. diabolus (pair no. 18) (Figs. 1-2). Notably, the heterochromatic blocks in Trichomycterus sp. 2 appeared as proximal and equidistant bands on both chromosomal arms of all chromosomes (Fig. 2).

FISH analyses revealed distinct genomic locations for the ribosomal sites. Whereas from 2 to 6 sites per genome of $18 \mathrm{~S}$ rDNA could be observed, a variation from 2 to 8 sites per genome for the minor ribosomal DNA was detected. For the species T. davisi, T. paulinus and Trichomycterus sp. 2 the $18 \mathrm{~S}$ rDNA was located on the short arm of the second metacentric pair, while in T. diabolus, these sites were located on the lon arms of this same pair (Fig. 3b). In addition, Trichomycterus sp. 2 also showed an extra site in a small metacentric pair (Figs. $3 \mathrm{a}, \mathrm{c}, \mathrm{e})$. Trichomycterus sp. 3 showed signals on the long arms of pair no. 1 (Fig. 3d). In T. iheringi the $18 \mathrm{~S}$ rDNA clusters were located on the long arms of the first submetacentric pair, while in T. mimonha these sites were located in the short arms of this same pair (Figs. 3f-g). Finally, only two species showed more than two pairs bearing 18S rDNA, which includes $T$. zonatus and Trichomycterus sp. 1 (Figs. 3h- i).

Regarding the minor ribosomal sites, they were co-located with the $18 \mathrm{~S}$ rDNA clusters in all species, except in $T$. iheringi (Fig. 3f). While the 18S rDNA was located in a single pair in almost every species, except in T. zonatus, Trichomycterus sp. 2, and Trichomycterus sp. 1, (Figs. 3h, e, i). Thus, T. davisi, T. diabolus, T. paulinus, Trichomycterus sp. 3, T. iheringi and Trichomycterus sp. 1 showed a single pair of $5 \mathrm{~S}$ rDNA; $T$. zonatus and Trichomycterus sp. 2 showed two pairs; and T. mimonha presented 4 pairs (Figs. 3a,-d, f, i, h, e, g).
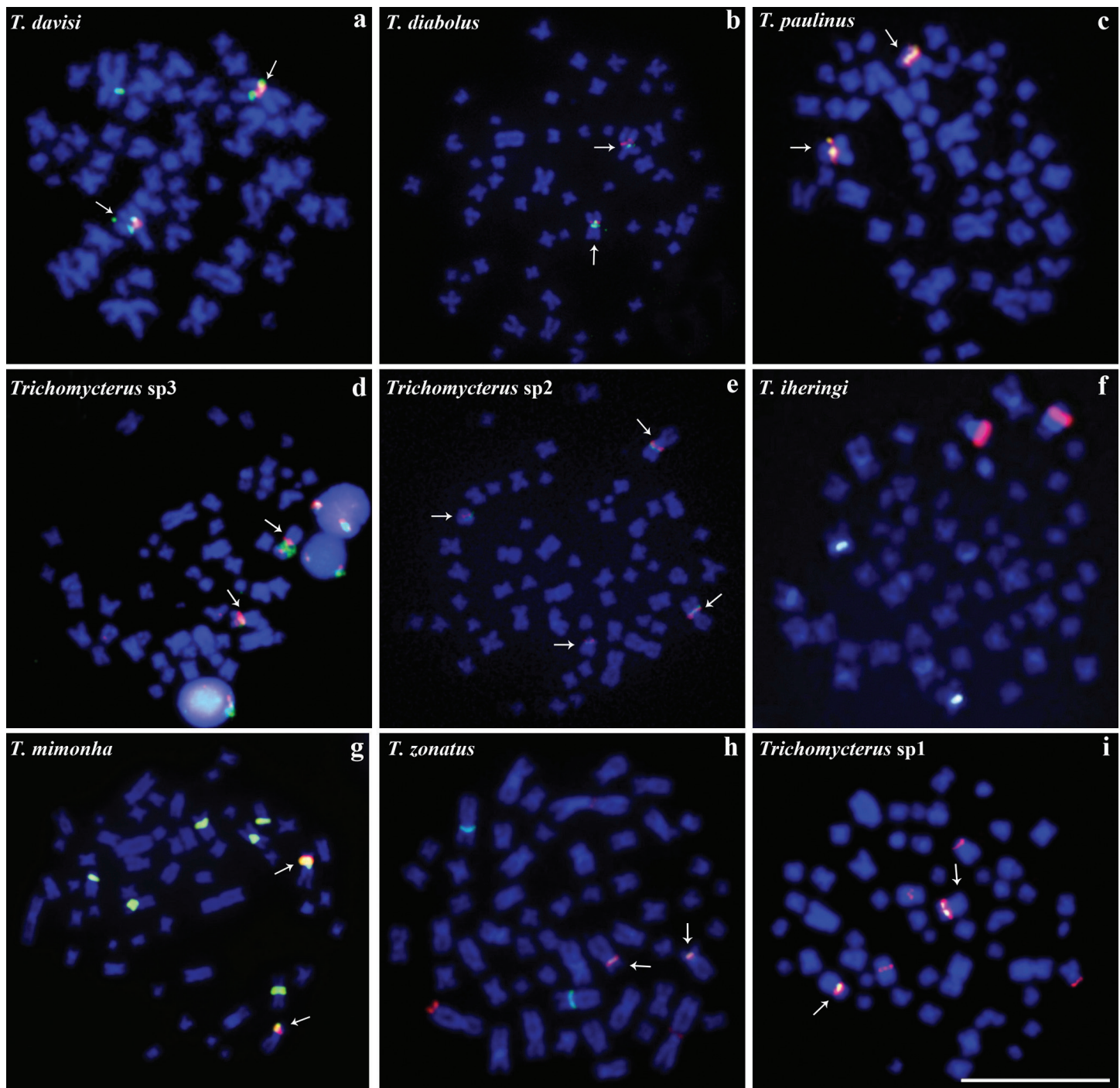

Fig. 3. Distribution pattern of $5 \mathrm{~S}$ (green) and $18 \mathrm{~S}$ rDNA sites (red) in metaphase of nine species of Trichomycterus analyzed: a) T. davisi; b) T. diabolus; c) T. paulinus; d) Trichomycterus sp. 3; e) Trichomycterus sp. 2; f) T. iheringi; g) T. mimonha; h) T. zonatus; and i) Trichomycterus sp. 1. Note co-localization between $5 \mathrm{~S}$ and $18 \mathrm{~S}$ rDNA sites occurring at least in one chromosome pair in all the species and are evidenced by the white arrows. Bar $=10 \mu \mathrm{m}$. 


\section{Discussion}

The results obtained here are in accordance with previous studies about diploid chromosome numbers and basic karyotype structure in distinct cis-Andean Trichomycterus species (Sato et al., 2004). However, comparing our results with available cytogenetic data for this group, one must note that remarkable differences in the karyotypic formulae are evident, mainly related to the number of meta- and submetacentric chromosomes in each species or even within a single species (Torres et al., 2004; Vicari et al., 2010).

According to Borin \& Martins-Santos (2000), pericentric inversions would be the main mechanism of karyotype diversification in this group. Such hypothesis was based on the remarkable differences found in karyotype formulae of different species, in spite of a conserved diploid chromosome number. Our results are in accordance with this hypothesis, but also evidenced other significant interespecific chromosome changes, including: i) variations in the amount and distribution of constitutive heterochromatin; ii) differences in the chromosomal location of minor and major ribosomal sites; and even iii) the occurrence of mitotically unstable supernumerary chromosomes in three species. Considering this scenario, it can be suggested that additional genomic alterations in distinct levels of chromosomal resolution also play a role in the karyotype diversification of Trichomycterus.

Based on the general karyotype patterns and the NOR position, Sato et al. (2004) sub classified several Trichomycterus species into two main groups. The first one comprised species presenting the first metacentric chromosome pair as the largest of the karyotype and the NORs located on the short arm of the first submetacentric pair, while the second group comprised those species with the first two metacentric chromosomes as the largest chromosomes of the karyotype and the NORs located on the long arm of pair 2. Indeed, some of the species herein analyzed fit in this classification. However, species like $T$. iheringi, T. davisi, Trichomycterus sp. 1, Trichomycterus sp. 2, and Trichomycterus sp. 3 do not fit perfectly in any group. For example, Trichomycterus sp. 2 presents a single large metacentric, characteristic of group 1, while the NORs are located on the short arms of the second metacentric pair. Therefore, our data indicate that the karyotypes of Trichomycterus cannot be simply classified into two single groups, mainly because of the variable positions of the NORs in different species as found here. Considering that $18 \mathrm{~S}$ rDNA-carrier chromosomes presents a similar relative size in almost all species, it can be suggested that multiple pericentric inversions in this same chromosome might have given rise to the current situation.

Differential accumulation of heterochromatin in the genomes of the distinct species is a notable feature in Trichomycterus. While some species show small and weak heterochromatic blocks (e.g. T. diabolus), others exhibit conspicuous centromeric and pericentromeric blocks (e.g. T. iheringi and Trichomycterus sp. 2). Such heterochromatin dynamics would possibly be explained by the role played by transposable elements and/or ectopic recombination (Vicari et al., 2010). Moreover, the presence of heterochromatic regions near to the centromere may facilitate breaks, which could possibly explain the occurrence of pericentric inversions in NOR-bearing chromosomes, as pointed by Borin \& Martins-Santos (2000).

Physical mapping of $18 \mathrm{~S}$ rDNA sites revealed a two sites per genome for almost every species, except for T. zonatus, Trichomycterus sp. 1 and Trichomycterus sp. 2. Additionally, co-localization of the major and minor ribosomal sites was also found in almost all the analyzed species, independently of the arm ratio of these chromosomes, reinforcing the hypothesis that pericentric inversions occurs within the NOR regions. Interestingly, the syntenic condition between ribosomal genes was also detected in other closely related fish species (Ziemniczak et al., 2012). Although it represents a widespread, conserved and plesiomorphic condition in Trichomycterus, the colocalization between ribosomal genes have emerged independently several times during the evolutionary history of different organisms, and most likely does not have any significant effect on fitness (Drouin \& de Sá, 1995; Vierna et al., 2011).

Ribosomal DNA sequences have been extensively mapped in several teleost species, evidencing a large degree of variation regarding their chromosomal location. Such diversification may be associated with several mechanisms of dispersion, including ectopic recombination and transposition events with the participation of extra chromosomal circular DNA and transposable elements. Considering that the 18S rDNA-bearing chromosomes of Trichomycterus are probably homeologous in all species, it can be suggested that minor ribosomal DNA sites are highly dynamic in this group.

Remarkably, since co-localization between $5 \mathrm{~S}$ and $18 \mathrm{~S}$ rDNA sites seems to be a plesiomorphic state in Trichomycterus, the spreading events of 5S rDNA sites might have occurred differentially in relation to the $18 \mathrm{~S}$ sequences. For example, i) $5 \mathrm{~S}$ rDNA might have moved to another genomic location carrying the $18 \mathrm{~S}$ rDNA together, like in Trichomycterus sp. 2; ii) $5 \mathrm{~S}$ rDNA might have moved to another genomic location, independently from the 18S rDNA, but maintaining the co-localization with the major rDNA, like in T. zonatus; or iii) $5 \mathrm{~S}$ rDNA might have moved to another genomic location, independently from the $18 \mathrm{~S}$ rDNA, thus disrupting the syntenic condition, like in $T$. iheringi. The present work supports the occurrence of a main trend towards the maintaining a chromosomal association of major and minor ribosomal genes in the genus Trichomycterus, despite the fact that a linked configuration of such genes is not functionally required (Hannan et al., 1998). A similar trend towards a linked chromosomal configuration of the two ribosomal gene 
families, associated with similar spreading events of $5 \mathrm{~S}$ rDNA sequences in extra-NORs chromosomes positions in some species, have been already described in notothenioid fish evolution (Pisano \& Ghigliotti, 2009).

The importance of transposable elements mediating extensive ribosomal DNA multiplications and spreading has been evidenced by several studies (Nakajima et al., 2012; Pansonato-Alves et al., 2013; Symonová et al., 2013). In general, these elements may be allocated within the intergenic spacers of ribosomal families, or even flanking these regions (Nakajima et al., 2012). The considerable variation in chromosomal location of 5S rDNA sites in Trichomycterus suggest that this ribosomal gene may be associated with transposable elements, which might have favored the spreading of these sites in the different species.

The numerical polymorphism found in T. paulinus; Trichomycterus sp. 1, and Trichomycterus sp. 3 were due to the occurrence of heterochromatic supernumerary chromosomes in their genomes. In general, this kind of chromosome is considered genetically dispensable and do not seems to confer any apparent function or selective advantage to the carriers (Camacho et al., 2000). They can arrive from the genome of another species, in an interespecific origin or from their actual host species, in an intraspecific origin. In the latter case, B chromosomes may have originated as by-products of genomic rearrangements, like chromosomal breakages. Remarkably, this hypothesis reinforces the intense genomic dynamics of Trichomycterus species and, consequently, some species might keep B chromosomes as remnants of chromosome rearrangements occurred during the evolutionary history of this group. In addition, the heterochromatic nature of these elements is in accordance with the molecular evolution of B chromosomes, which involves gene silencing, heterochromatinization and accumulation of repetitive DNA (Camacho et al., 2000).

Our results corroborated the hypothesis that pericentric inversion is an important mechanism of diversification in Trichomycterus. Additionally, variations in the abundance of constitutive heterochromatin, the distribution of repetitive sequences and the occurrence of B chromosomes were also detected and seem to play an important role in the karyotype diversification of this group.

\section{Acknowledgements}

This study was supported by the Fundação de Amparo à Pesquisa do Estado de São Paulo (FAPESP), Coordenadoria de Aperfeiçoamento de Pessoal de Nível Superior (CAPES) and Conselho Nacional de Desenvolvimento Científico e Tecnológico $(\mathrm{CNPq})$ from Brazil.

\section{References}

Arratia, G. \& A. Veloso. 1980. Cariótipos de peces tricomicteridos (Siluriformes). Archivos de Biología Y Medicina Experimentales (Santiago), 13: 137.
Bonillo, C., J.-P. Coutanceau, H. D'Cotta, L. Ghigliotti, C. Ozouf-Costaz \& E. Pisano. 2015. Standard fluorescence in situ hybridization procedures. Pp. 103-118. In: OzoufCostaz, C., E. Pisano, F. Foresti \& L. F. A. Toledo (Eds.). Fish cytogenetic techniques - ray-fin fishes and chondrichthyans. Boca Raton, CRC Press, Taylor \& Francis Group.

Borin, L. A. \& I. C. Martins-Santos. 2000. Intra-individual numerical chromosomal polymorphism in Trichomycterus davisi (Siluriformes, Trichomycteridae) from the Iguaçu River basin in Brazil. Genetics and Molecular Biology, 23: 605-607.

Camacho, J. P. M., T. F. Sharbel \& L. W. Beukeboom. 2000. B-chromosome evolution. Philosophical Transactions of the Royal Society of London B: Biological Sciences, 355: 163-178.

Cole, C. J. \& C. R. Levans. 1971. Chromosome preparations of amphibians and reptiles: improved technique. Herpetological Review, 3: 102.

de Pinna, M. C. C. \& W. Wosiacki. 2003. Family Trichomycteridae (Pencil or parasitic catfishes). Pp. 270-290. In: Reis, R. E., S. O. Kullander, C. J. Ferraris, Jr. (Orgs.). Checklist of the freshwater fishes of South and Central America. Porto Alegre, Edipucrs.

Drouin, G. \& M. M. de Sá. 1995. The concerted evolution of 5S ribosomal genes linked to the repeat units of other multigene families. Molecular Biology and Evolution, 12: 481-493.

Foresti, F., L. F. A. Toledo \& S. A. Toledo Filho. 1981. Polymorphic nature of nucleolus organizer regions in fishes. Cytogenetics and Cell Genetics, 31: 137-144.

Froese, R. \& D. Pauly (Eds.). 2014. FishBase. World Wide Web electronic publication: www.fishbase.org. (02 December 2014).

Hannan, K. M., R. D. Hannan \& L. I. Rothblum. 1998. Transcription by RNA polymerase I. Frontiers in Bioscience, 3: d376-398.

Levan, A., K. Fredga \& A. A. Sandberg. 1964. Nomenclature for centromeric position on chromosomes. Hereditas, 52: 201-220.

Nakajima, R. T., D. C. Cabral-de-Mello, G. T. Valente, P. C. Venere \& C. Martins. 2012. Evolutionary dynamics of rRNA gene clusters in cichlid fish. BMC Evolutionary Biology, 12: 198.

Oliveira, C., L. F. A. Toledo, F. Foresti, H. A. Britski \& S. A. Toledo Filho. 1988. Chromosome formulae of Neotropical freshwater fishes. Revista Brasileira de Genética, 11: 577-624.

Pansonato-Alves, J. C., E. A. Serrano, R. Utsunomia, P. C. Scacchetti, C. Oliveira \& F. Foresti. 2013. Mapping five repetitive DNA classes in sympatric species of Hypostomus (Teleostei: Siluriformes: Loricariidae): analysis of chromosomal variability. Reviews in Fish Biology and Fisheries, 23: 477-489.

Pendas, A. M., P. Moran, J. Freije \& E. Garcia-Vazquez. 1994. Chromosomal mapping and nucleotide sequence of two tandem repeats of Atlantic salmon 5S rDNA. Cytogenetics and Cell Genetics, 67: 31-36.

Pisano, E. \& L. Ghigliotti. 2009. Ribosomal genes in notothenioid fishes: focus on the chromosomal organisation. Marine Genomics, 2: 75-80. 
Sarmento-Soares, L. M., A. M. Zanata \& R. F. Martins-Pinheiro. 2011. Trichomycterus payaya, new catfish (Siluriformes: Trichomycteridae) from headwaters of rio Itapicuru, Bahia, Brazil. Neotropical Ichthyology, 9: 261-271.

Sato, L. R., C. Oliveira \& F. Foresti. 2004. Karyotype description of five species of Trichomycterus (Teleostei: Siluriformes: Trichomycteridae). Genetics and Molecular Biology, 27: 45-50.

Symonová, R., Z. Majtánová, A. Sember, G. B. O. Staaks, J. Bohlen, J. Freyhof, M. Rábová \& P. Ráb. 2013. Genome differentiation in a species pair of coregonine fishes: an extremely rapid speciation driven by stress-activated retrotransposons mediating extensive ribosomal DNA multiplications. BMC Evolutionary Biology, 13: 42.

Sumner, A. T. 1972. A simple technique for demonstrating centromeric heterochromatin. Experimental Cell Research, 75: 304-306.

Torres, R. A., F. Foresti \& C. Oliveira. 2002. Occurrence of karyotypical mosaicism in Trichomycterus paolence (Teleostei, Trichomycteridae). Caryologia, 55: 283-287.

Torres, R. A., C. Oliveira \& F. Foresti. 2004. Cytotaxonomic diagnosis of Trichomycterus diabolus (Teleostei: Trichomycteridae) with comments about its evolutionary relationships with co-generic species. Neotropical Ichthyology, 2: 123-125.

Vicari, M. R., V. Nogaroto, R. B. Noleto, M. M. Cestari, M. B. Cioffi, M. C. Almeida, O. Moreira-Filho, L. A. C. Bertollo \& R. F. Artoni. 2010. Satellite DNA and chromosomes in Neotropical fishes: methods, applications and perspectives. Journal of Fish Biology, 76: 1094-1116.
Vierna, J., K. T. Jensen, A. Martínez-Lage \& A. M. GonzálezTizón. 2011. The linked units of 5S rDNA and U1 snDNA of razor shells (Mollusca: Bivalvia: Pharidae). Heredity, 107: 127-142.

White, T. J., T. Bruns, S. Lee \& J. Taylor. 1990. Amplification and direct sequencing of fungal ribosomal RNA genes for phylogenetics. Pp. 315-322. In: Innis, M. A., D. H. Gelfand, Jr., J. Sninsky \& T. J. White (Eds.). PCR Protocols: a guide to methods and applications. San Diego, Academic Press.

Wosiacki, W. B. \& J. C. Garavello. 2004. Five new species of Trichomycterus from the rio Iguaçu (rio Paraná basin), southern Brazil (Siluriformes: Trichomycteridae). Ichthyological Exploration of Freshwaters, 15: 1-16.

Wosiacki, W. B. \& M. C. C. de Pinna. 2007. Família Trichomycteridae: Trichomycterinae. Pp. 68-72. In: Buckup, P. A., N. A. Menezes \& M. S. Ghazzi (Eds.). Catálogo das espécies de peixes de água doce do Brasil. Rio de Janeiro, Museu Nacional.

Ziemniczak, K., A. V. Barros, K. O. Rosa, V. Nogaroto, M. C. Almeida, M. M. Cestari, O. Moreira-Filho, R. F. Artoni \& M. R. Vicari. 2012. Comparative cytogenetics of Loricariidae (Actinopterygii: Siluriformes): emphasis in Neoplecostominae and Hypoptopomatinae. Italian Journal of Zoology, 79: 492-501.
Submitted June 10, 2015 Accepted March 07, 2016 by Alexandre Hilsdorf 